\title{
Ultrasensitive carbohydrate-peptide SPR imaging microarray for diagnosing IgE mediated peanut allergy
}

\author{
Amit A. Joshi ${ }^{\mathrm{a}}$, Mark W. Peczuh ${ }^{\mathrm{a}}$, Challa V. Kumar ${ }^{\mathrm{a}, \mathrm{b}}$, and James F Ruslinga,c,d \\ aDepartment of Chemistry, U-3060, University of Connecticut, Storrs, CT 06269-3060 USA Fax: \\ (+1) 860-486-2981

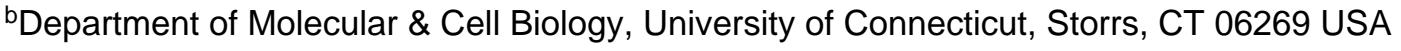 \\ 'Institute of Materials Science, University of Connecticut, Storrs, CT 06269-3060 USA \\ dDepartment of Cell Biology, University of Connecticut Health Center Farmington, CT 06032 USA
}

\section{Abstract}

Severity of peanut allergies is linked to allergen-specific immunoglobulin E (IgE) antibodies in blood, but diagnostics from assays using glycoprotein allergen mixtures may be inaccurate.

Measuring IgEs specific to individual peptide and carbohydrate epitopes of allergenic proteins is promising. We report here the first immunoarray for IgEs utilizing both peptide and carbohydrate epitopes. A surface plasmon resonance imaging (SPRi) microarray was equipped with peptide and $\beta$-xylosyl glycoside (BXG) epitopes from major peanut allergen glycoprotein Arachis hypogaea h2 (Ara-h2). A monoclonal anti-IgE antibody was included as positive control. IgEs were precaptured onto magnetic beads loaded with polyclonal anti-IgE antibodies to enhance sensitivity and minimize non-specific binding. As little as 0.1 attomole $(0.5 \mathrm{pg} / \mathrm{mL}) \operatorname{IgE}$ was detected from dilute serum in 45 min. IgEs binding to Ara-h2 peptide and BXG were quantified in $10 \mu \mathrm{L}$ of patient serum and correlated with standard ImmunoCAP values.

\section{Introduction}

Allergies to peanuts and tree nuts are critical issues for millions of people worldwide. ${ }^{1,2}$ Severe allergic reactions to nuts can lead to anaphylactic shock, hospital visits and death. ${ }^{3}$ Allergen epitope-resolved arrays are a promising strategy to improve diagnostic specificity for serum immunoglobulin antibodies (IgEs) to these allergens. ${ }^{4}$ Here we report the first peptide-carbohydrate SPRi immunoarray aimed at diagnosis of peanut allergies. It features spots of a 28-mer peptide sequence residues 39-66 from peanut protein Ara h2, 5 a $\beta$-xylosyl glycoside present on the central mannose residue of $N$-linked glycoproteins, ${ }^{6}$ and an anti-IgE antibody to achieve quantitative detection of human allergen-specific IgEs.

Arachis hypogaea (Ara-h1 to Ara-h8) glycoproteins are the major peanut allergens recognized by serum IgEs in allergic individuals. ${ }^{7,} 8$ Amongst these, Ara-h2 is the most potent allergen. ${ }^{9}$ Specific IgE levels against epitopes of Ara-h2 are predicted to be reliable

Electronic Supplementary Information (ESI) available: [details of any supplementary information available should be included here]. See DOI: $10.1039 / \mathrm{b} 000000 \mathrm{x} /$ 
diagnostic biomarkers for severity of peanut allergies. ${ }^{10}$ Specific peptide epitopes have been used for detecting IgEs by a fluorescent immunoassay. ${ }^{11-13}$ Our previous studies employed the same Ara-h2 peptide to detect an allergen-specific model for IgEs, chicken IgY antibody, by electrochemical immunoassays ${ }^{14}$ and a resistive pulse nanosensor. ${ }^{15}$

Nearly all Ara-h glycans are linked through asparagine residues ( $N$-linked).${ }^{16}$ They are referred to as Cross-reactive Carbohydrate-Determinants (CCDs) because they are present on many plant glycoproteins. Consequently, IgEs reactive to this moiety on one allergen can demonstrate cross-reactivity with other allergens. ${ }^{16} \mathrm{~N}$-glycans containing a $\beta$-linked xylose on the central mannose of the core pentasaccharide and an a-linked fucose at the reducingend GlcNAc are the main epitopes recognized by cross reactive IgEs. ${ }^{6}$ The significance of CCDs to allergy are controversial because they have been implicated in false positive diagnoses by skin-prick and quantitative IgE tests. ${ }^{17}$ Methods to quantify CCD-specific IgEs have been reported using model $\mathrm{N}$-linked glycoproteins such as bromelain or horseradish peroxidase as capture agents, ${ }^{18-20}$ although their $\mathrm{N}$-glycans are not the same as those of Ara$h$ proteins. A positive $\mathrm{CCD}$ test can, however, qualify the interpretation of standard $\operatorname{IgE}$ (e.g., ImmunoCAP) assays for physicians and alert them to possible false positives. ${ }^{21}$ One prevailing view is that no single diagnostic test at present reliably predicts the severity of peanut allergy. ${ }^{22}$ To the best of our knowledge, peptide sequences and carbohydrate residues have not been used together in an array to detect specific IgE antibodies.

Scheme 1 depicts the SPRi microarray with spots featuring the Ara-h2 peptide, $\beta$-xylosyl glycoside (BXG) (see supporting information for synthesis), and monoclonal anti-human IgE as positive control. The Ara-h2 peptide and BXG were equipped with terminal amine groups to facilitate chemical linkage onto carboxylated gold SPRi sensor slides. Since individual epitope-specific anti-peanut IgEs are not commercially available, we used an available human IgE mixture as a standard. SPRi is not sufficiently sensitive to measure protein biomarkers at sub-pg/mL levels. Thus, we used magnetic bead amplification to overcome this limitation. Magnetic beads coated with $\sim 60,000$ polyclonal $\varepsilon$-chain specific anti-human IgE antibodies (MP-Ab ${ }_{2}$ ) were used to capture IgEs from samples. These $1 \mu \mathrm{m}$ diam. iron oxide-poly(styrene) beads greatly amplify SPR signals by increasing the refractive index in the detection window of the SPR sensor. ${ }^{23} \mathrm{MP}^{-\mathrm{Ab}_{2}}$ beads with captured IgEs were washed, separated magnetically, then redispersed and injected into the flow system to deliver them to the gold SPRi chip, where SPR signals for spots are imaged simultaneously. Capture on magnetic beads facilitates separation of IgEs from the complex serum mixture. In this approach, only target antibodies, but not potentially interfering biomolecules, enter the SPRi array, thereby minimizing non-specific binding on the SRP sensor. This is quite important for a method like SPR in which any biomolecule adsorbed on the sensor surface will contribute to the signal.

\section{Results and Discussion}

\section{Kinetics of Antibody binding to allergen epitopes}

To ascertain binding strengths on SPR chips before developing the full analytical protocol, we first studied the binding kinetics of chicken IgY and the human IgE mixture onto the Ara-h2 peptide and BXG spots on the microarray. We estimated apparent dissociation 
constants of these antibody mixtures after binding to allergen epitopes attached to the SPR sensor surface. For IgY binding, allergen probes were first attached to the activated mixed thioalkyl-PEG-carboxylate monolayer on a conventional gold SPR chip using 1-ethyl-3-(3dimethylaminopropyl) carbodiimide (EDC) and $N$-hydroxysuccinimide (NHS) to promote amide bond formation. Attachments of probes to the chip were monitored by the SPR response (Figure S1-A), resulting in estimated ligand densities of $\sim 3 \times 10^{11}$ molecules $/ \mathrm{mm}^{2}$. The response for BXG was smaller than that of the Ara-h2 peptide presumably because of its smaller molar mass.

The binding data for IgY and IgE samples were fit using an equilibrium associationdissociation model (eqs 1 and 2). Simultaneous non-linear regression analysis onto these equations provided the global minimum sum of squares resulting in the best values of association rate constant $\mathrm{k}_{\mathrm{a}}$ and dissociation rate constant $\mathrm{k}_{\mathrm{d}}$. Apparent dissociation constant, $\mathrm{K}_{\mathrm{D}}$ was obtained using eq 3 .

$$
\begin{gathered}
\mathrm{R}_{\mathrm{t}}=\mathrm{Ck}_{\mathrm{a}} \mathrm{R}_{\max }\left[1-\exp -\left(\left(\mathrm{Ck}_{\mathrm{a}}+\mathrm{k}_{\mathrm{d}}\right) \mathrm{t}\right)\right] /\left(\mathrm{Ck}_{\mathrm{a}}+\mathrm{k}_{\mathrm{d}}\right) \\
\mathrm{R}_{\mathrm{t}}=\mathrm{R}_{\max } \exp \left(-\mathrm{k}_{\mathrm{d}} \mathrm{t}\right) \\
\mathrm{K}_{\mathrm{D}}=\mathrm{k}_{\mathrm{d}} / \mathrm{k}_{\mathrm{a}}
\end{gathered}
$$

Clearly, these studies do not provide absolute dissociation constants, but they provide relative binding strengths of the free antibody-allergen pairs that will be used for analysis of patient samples. Figure S1-B shows that binding of free IgY to the allergen probes immobilized on the gold SPR chip gave good fits to this model. The affinity of human IgEs to array ligands was measured directly by the SPRi system. The sixteen gold spots on the chip were functionalized with carboxylate groups as reported previously using 1:9 thiolalkane- $\mathrm{PEG}_{6}$-COOH: thiolalkane- $\mathrm{PEG}_{3}-\mathrm{OH} .{ }^{24}$ Anti-IgE monoclonal antibody, Ara-h2 peptide and BXG with amine linkers were covalently attached to the carboxyl groups on individual spots by EDC/NHS amidation. Unreacted carboxyl groups were blocked by using $1 \mathrm{M}$ glycine, $\mathrm{pH}$ 8. Control BSA responses were subtracted from responses for individual capture probes to correct for non-specific binding of IgE. SPRi data gave good non-linear regression fits onto eqs 1 and 2 (Figure 1) to provide rate and dissociation constants (Table $1)$.

Apparent dissociation constants in the low nanomolar range show that the free $\operatorname{Ig} \mathrm{Y}$ and $\operatorname{IgE}$ antibodies bind strongly to BGX and Ara h2 peptide spots on the Au SPRi array. We previously found strong binding of IgY to Ara h2 peptide in electrochemical sensors. ${ }^{14}$ Similar strength of binding between anti-CCD antibodies and the xylose portion of Nglycans has been reported, with apparent dissociation constant $4.7 \mathrm{nM}$ for anti-CCD antibodies binding to xylose region of N-glycan attached onto an SPR sensor. ${ }^{25}$ Further, strong binding of IgE to N-Glycans containing both $\beta(1,2)$ xylose and $\alpha(1,3)$ fucose was reported with equilibrium dissociation constants of $68 \mathrm{pM} .{ }^{26}$ Our results are consistent with those findings. The low dissociation constants suggest that $\operatorname{IgE}$ antibodies bind very strongly 
with carbohydrate residues and Ara h2 peptide spots on the SPR array, and suggests that SPRi should be effective for quantitative detection of the IgEs. Strong avidity between IgEs and surface ligand spots could possibly be influenced by the bivalent nature of $\operatorname{IgE}$ antibodies. $^{27}$

Apparent dissociation constants $\left(\mathrm{K}_{\mathrm{D}}\right)$ for human $\mathrm{IgE}$ binding to the ligands were smaller than those for chicken $\operatorname{IgY}$, indicating stronger binding of the IgEs with $K_{D}$ values of 1-3 $\mathrm{nM}$. To a first approximation, the association $\mathbf{k}_{\mathbf{a}}$ for binding of $\operatorname{IgE}$ and $\operatorname{IgY}$ on the BXG and Ara-h2 peptide spots are roughly the same, but the dissociation $\mathbf{k}_{\mathbf{d}}$ of IgE are much smaller, leading to smaller apparent $\mathrm{K}_{\mathrm{D}}$ values. $\mathrm{K}_{\mathrm{D}}$ 's of IgE on Ara-h2 peptide, $\mathrm{BXG}$ and anti-IgE were not significantly different at the $95 \%$ confidence interval (t-test). This suggests that IgEs bind to both probes equally well.

\section{Detection of IgE using MP-Ab 2 conjugate}

Magnetic beads conjugated with $\sim 60,000$ polyclonal $\varepsilon$-chain specific anti-human $\operatorname{IgE}$ antibodies $\left(\mathrm{MP}-\mathrm{Ab}_{2}\right)$ were prepared as described in SI. These MP-Ab $\mathrm{b}_{2}$ conjugates easily capture and separate IgEs from complex serum mixture. IgEs were pre-captured onto MP$\mathrm{Ab}_{2}$, then washed and redispersed. The beads were subsequently injected into the SPRi. Bright spots in background-subtracted array images reflect specific binding of MP- $\mathrm{Ab}_{2}-\mathrm{IgEs}$ onto the detection probes and the positive anti-IgE control (Figure 2-A). Little response was seen on negative control BSA spots.

\section{Assay Validation}

Five serum samples from patients who had allergic reactions to peanuts at some time in their lives were obtained from the serum bank at the Elliot and Roslyn Jaffe Food Allergy Institute, Mt Sinai Medical Center, NY. These samples were analyzed with the SPRi array after 1000 to 5000 -fold dilution of $10 \mu \mathrm{L}$ in buffer (see SI) to bring SPR responses into the linear range of the assay. Samples were categorized by standard ImmunoCAP values in two ranges. Samples 3-5 (Fig. 4), with a minimum IgE level of $>10 \mathrm{kU} / \mathrm{L}$ i.e. $24 \mathrm{ng} / \mathrm{mL}$ (1 kU/L $=2.42 \mathrm{ng} / \mathrm{mL}$ ), had "high" IgE titres, whereas samples 1 and 2 had "low" titres between $0.5-2.0 \mathrm{kU} / \mathrm{L}(1.2-4.8 \mathrm{ng} / \mathrm{mL}) .{ }^{28}$ ImmunoCAP measures specific IgE levels against combined peanut allergen extracts as capture agents. ${ }^{29}$ SPRi clearly differentiated between high and low IgE levels consistent with ImmunoCAP results (Figure 4). IgE concentrations determined by SPRi using anti-IgE antibody, Ara-h2 peptide and BXG ligand were statistically indistinguishable as shown by t-tests although anti-IgE tended to give slightly larger values and Ara-h2 gave slightly lower values. This result is logical based on the design of the assay. Specifically, the polyclonal antibody used to capture serum IgEs onto $M P-A b_{2}$ is not selective but rather collects all serum IgEs. Therefore, each MP-Ab 2 bead had captured IgEs reactive to both the Ara-h2 peptide and BXG allergen spots. That is, the MP- $\mathrm{Ab}_{2}$ particles do not exclusively capture IgEs that react to only one epitope, somewhat compromising assay selectivity. There is reason to expect that IgEs for Ara-h2 peptide and BXG will have different populations in serum. With modifications of experimental design to improve bead binding selectivity, we should be able to differentiate these populations by epitope-resolved detection of serum IgEs. 
Figure 2-B shows SPR signals after injection of $10 \mathrm{pg} \mathrm{mL}^{-1} \mathrm{IgE}$ in 1000 -fold diluted serum. The intensity of control BSA spots was subtracted from detection spots to compensate for non-specific binding. SPR association responses for MP- $\mathrm{Ab}_{2}-\mathrm{IgE}$ did not fit eq. 1. Further, signals did not decrease after switching to buffer (dashed line, Figure 2B). This suggests very low $\mathrm{K}_{\mathrm{D}}$ values of $\mathrm{MP}-\mathrm{Ab}_{2}-\mathrm{IgE}$ on the three probes. The current situation is similar to MP- $\mathrm{Ab}_{2}$ captured by protein antigens attached to gold SPR sensors in previous studies, where we estimated upper limit $\mathrm{K}_{\mathrm{D}}$ 's in the low $\mathrm{fM}$ range.30 As in that study, the low apparent dissociation rate is related to high local $\mathrm{Ab}_{2}$ concentrations that favor antigen binding but not dissociation and could also be influenced by possible cooperative multivalent binding to the surface.

Calibration plots for IgE in 1000 -fold diluted calf serum using the MP-Ab $\mathrm{A}_{2}$ assay protocol showed that SPR response increased with increasing concentration in the $\mathrm{pg} \mathrm{mL}^{-1}$ range (Figure 3) in 45 min assays. Detection limits for $40 \mu \mathrm{L}$ solutions were $0.5 \mathrm{pg} \mathrm{mL}^{-1}$ on BXG spots $(0.1 \mathrm{amol})$ and $1 \mathrm{pg} \mathrm{mL}^{-1}(0.2 \mathrm{amol})$ on anti-IgE and Ara h2 peptide spots. Similar relative sensitivities of $5.5\left[\log \left(\mathrm{pg} \mathrm{mL}^{-1}\right)\right]^{-1}$ on anti-IgE, 4.7 on peptide and 4.9 on BXG spots were achieved.

\section{Conclusions}

We demonstrate here the first SPRi immunoarray featuring peptide and carbohydrate allergen binding moieties for peanut allergen IgE antibodies. Magnetic particles coated with $\sim 60,000$ secondary anti-IgE antibodies were used to capture IgEs from serum, and these were in turn bound directly onto specific epitope spots on the SPRi chip to detect subattomole levels of IgEs from serum samples. The magnetic beads greatly enhance SPRi signals by increasing the refractive index of the binding moiety, and increasing apparent binding constants of $\operatorname{IgE}$, so that detection limits of $0.5-1 \mathrm{pg} \mathrm{mL}^{-1}(0.1-0.2$ attomole) were achieved. Using magnetic beads, we achieved pre-capture of the analytes to minimize nonspecific binding, and amplification of the SPR signal. This approach should facilitate detection of very low levels of antibodies of any type. In our previous work, ultralow detection limits of the protein prostate specific antigen were achieved by conventional SPR in pure serum using pre-capture on magnetic beads. ${ }^{23}$ Similarly, it should be possible to detect IgE antibodies in pure serum with little compromise of sensitivity.

The immunoarray was used to quantitate peptide and xylose binding of serum IgEs in $10 \mu \mathrm{L}$ patient serum samples. IgE's bound to these spots determined by SPRi correlated well with the clinically-used ImmunoCAP assay. The technology described here is amenable to developing a future microarray with multiple allergen peptide and carbohydrate epitopes to characterize severity of peanut allergy. Specific to the present work, we anticipate that future microarrays will differentiate between IgEs that bind to protein/peptide versus glycan epitopes. 


\section{Experimental}

\section{Chemicals and Materials}

A full list of source of chemicals and experimental procedures are in the supporting information (SI) file. Ara $\mathrm{h} 2$ peptide fragment with terminal amine group $\left(\mathrm{H}_{2} \mathrm{~N}-\right.$ QSPSYPDREYSDEDRQIKQMLHQECPRL-CONH $2,3450 \mathrm{Da}$, predicted IEP 4.95) was synthesized by Anaspec. $\beta$-xylose with a butylamine linker was synthesized as in SI. Monoclonal Anti-Human $\operatorname{IgE}\left(\mathrm{Ab}_{1}\right)$ and polyclonal $\varepsilon$-chain specific anti-human $\operatorname{IgE}\left(\mathrm{Ab}_{2}\right)$ were from Sigma Aldrich. Human IgE antibody (clone HE1) was from Thermo Scientific. Carboxyl-functionalized superparamagnetic particles (BioMagPlus, No. 86011) were from Polysciences Inc.,

\section{Kinetics of antibody binding to allergen Epitopes}

Binding of IgE antibody to allergen epitopes was studied using an SPR imager II from GWC technologies interfaced with syringe pump and injection valve. Microarrays were fabricated on SpotReady ${ }^{\mathrm{TM}} 16$ SPRi chip (No. SPR-1000-016, GWC). The SpotReady ${ }^{\mathrm{TM}}$ sensor chip features 16 gold spots, which were functionalized as reported previously using 1:9 ratio of monothiol alkane $\mathrm{PEG}_{6}-\mathrm{COOH}$ : monothiol alkane $\mathrm{PEG}_{3}-\mathrm{OH}^{2}{ }^{24}$ Carboxyl groups were activated with EDC and NHS for 10 min followed by coupling amine groups of anti-IgE, peptide, and $\beta$-xylose for 3 hours at room temperature in a humidified chamber. Then sensor chip was assembled into the SPR imaging instrument. $10 \mathrm{mM}$ phosphate buffered saline containing $0.05 \%$ Tween 20 (PBS-T) was used as running buffer. $1 \mathrm{M}$ glycine, $\mathrm{pH}$ 8.2, at 20

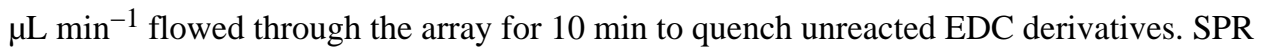
response was monitored in real time at $50 \mu \mathrm{L} \mathrm{min}^{-1}$ for association phase of $300 \mathrm{~s}$ and dissociation phase of 300 seconds by injecting series of antibody concentrations.

Background subtracted response curves were analyzed using Graphpad Prism 5.0 Software. A dual channel surface plasmon resonance spectrophotometer, SR700DC from Reichert Analytical Instruments (NY, USA) was used to study binding kinetics of chicken IgY on allergen spots.

\section{Detection of IgEs using MP-Ab2}

Carboxyl functionalized $1 \mu \mathrm{m}$ magnetic beads were bioconjugated with secondary anti-IgE antibodies $\left(\mathrm{MP}-\mathrm{Ab}_{2}\right)$ as described in SI. IgEs from diluted serum were captured on the above MP- $\mathrm{Ab}_{2}$ beads. $40 \mu \mathrm{L}$ of MP-Ab $\mathrm{Ab}_{2}$ stock dispersion was diluted with $320 \mu \mathrm{L}$ of PBS-T buffer $(0.05 \%$ Tween-20). To this dispersion, $40 \mu \mathrm{L}$ of human IgE reconstituted in 1000 -fold diluted calf serum was added. This mixture was incubated at $37^{\circ} \mathrm{C}$ for 30 min with continuous mixing. To discard unbound IgEs, the mixture was magnetically separated and supernatant fluid was removed. Beads were then washed three times with PBS-T, and final volume was made up to $400 \mu \mathrm{L}$ with PBS-T before detection.

\section{Supplementary Material}

Refer to Web version on PubMed Central for supplementary material. 


\section{Acknowledgments}

This work was supported by Grant No. EB014586 from the National Institute of Biomedical Imaging and Bioengineering (NIBIB), NIH (JFR) and DMR 1441879 from NSF (CVK). We thank Dr. S. H. Sicherer at the Elliot and Roslyn Jaffe Food Allergy Institute, Mt Sinai Medical Center, NY for supplying serum samples from the Food Allergy Research and Education funded repository.

\section{Notes and references}

1. Sicherer SH, Sampson HA. J Allergy Clin Immunol. 2010; 125:116. [PubMed: 19962747]

2. Sicherer SH, Sampson HA. J Allergy Clin Immunol. 2007; 120:491. [PubMed: 17689596]

3. Bock SA, Munoz-Furlong A, Sampson HA. J Allergy Clin Immunol. 2007; 119:1016-1018. [PubMed: 17306354]

4. De Knop KJ, Bridts CH, Verweij MM, Hagendorens MM, De Clerck LS, Stevens WJ, Ebo DG. Adv Clin Chem. 2010; 50:87-101. [PubMed: 20521442]

5. Stanley JS, King N, Burks AW, Huang SK, Sampson HA, Cockrell G, Helm RM, West CM, Bannon GA. Arch Biochem Biophys. 1997; 342:244. [PubMed: 9186485]

6. van Ree, Ronald; Cabanes-Macheteau, M.; Akkerdaas, J.; Milazzo, JP.; Loutelier-Bourhis, C.; Rayon, C.; Villalba, M.; Koppelman, S.; Aalberse, R.; Rodriguez, R.; Faye, L.; Lerouge, P. J Biol Chem. 2000; 275:11451. [PubMed: 10753962]

7. Kleber-Janke T, Crameri R, Appenzeller U, Schaalk M, Becker WM. Int Arch Allergy Immunol. 1999; 119:265. [PubMed: 10474031]

8. Bannon GA, Besler M, Hefle SL, Hourihane JO’B, Sicherer SH. Internet Symp Food Allergens. $2000 ; 2: 87$.

9. Lieberman JA, Glaumann S, Batelson S, Borres MP, Sampson HA, Nilsson C. J Allergy Clin Immunol: in Practice. 2013; 1:75.

10. Codreanu F, Collignon O, Roitel O, et al. Int Arch Allergy Immunol. 2011; 154:216. [PubMed: 20861643]

11. Shreffler WG, Beyer K, Chu THT, Burks AW, Sampson HA. J Allergy Clin Immunol. 2004; 113:776. [PubMed: 15100687]

12. Shreffler WG, Lencer DA, Bardina L, Sampson HA. J Allergy Clin Immunol. 2005; 116:893. [PubMed: 16210066]

13. Perry TT, Matsui EC, Conover-Walker MK, Wood RA. J Allergy Clin Immunol. 2004; 114:144. [PubMed: 15241358]

14. Liu H, Malhotra R, Peczuh MW, Rusling JF. Anal Chem. 2010; 82:5865. [PubMed: 20540504]

15. Wang Y, Kececi K, Mirkin MV, Mani V, Sardesai NP, Rusling JF. Chem Sci. 2013; 4:655. [PubMed: 23991282]

16. van Ree, Ronald. Int Arch Allergy Immunol. 2002; 129:189. [PubMed: 12444315]

17. Guilloux L, Morisset M, Codreanu F, Parisot L, Moneret-Vautrin DA. Int Arch Allergy Immunol. 2009; 149:91. [PubMed: 19127064]

18. Hemmer W, Focke M, Kolarich D, Wilson IB, Altmann F, Wöhrl S, Götz M, Jarisch R. J Allergy Clin Immunol. 2001; 108:1045. [PubMed: 11742287]

19. Kochuyt AM, Van Hoeyveld EM, Stevens EA. Clin Exp Allergy. 2005; 35:441. [PubMed: 15836751]

20. Mari A, Iacovacci P, Afferni C, Barletta B, Tinghino R, Di Felice G, Pini C. J Allergy Clin Immunol. 1999; 103:1005. [PubMed: 10359878]

21. Hemmer, W. Anticarbohydrate Antibodies. Kosma, P.; Muller-Loennies, S., editors. SpringerWien; New York: 2012. p. 181

22. Sheikh SZ, Wesley Burks A. Expert Rev Clin Immunol. 2013; 9:551. [PubMed: 23730885]

23. Krishnan S, Mani V, Wasalathanthri DP, Kumar CV, Rusling JF. Angew Chem Int Ed. 2011; 50:1175.

24. Lahiri J, Isaacs L, Tien J, Whitesides GM. Anal Chem. 1999; 71:777. [PubMed: 10051846] 
25. Jin C, Bencurova M, Borth N, Ferko B, Jensen-Jarolim E, Altmann F, Hantusch B. Glycobiology. 2006; 16:349. [PubMed: 16373330]

26. Jin C, Hantusch B, Hemmer W, Stadlmann J, Altmann F. J Allergy Clin Immunol. 2008; 121:185. [PubMed: 17881041]

27. Krishnamurthy, VM.; Estroff, LA.; Whitesides, GM. Fragment based approaches in drug discovery. Erlanson, D.; Jahnke, W., editors. Wiley-VCH; Weinheim, Germany: 2006. p. 34

28. Hamilton RG, Franklin Adkinson N Jr. J Allergy Clin Immunol. 2004; 114:213. [PubMed: 15316492]

29. Johansson S. Expert Rev Mol Diagn. 2004; 4:273. [PubMed: 15137895]

30. Mani V, Wasalathanthri DP, Joshi AA, Kumar CV, Rusling JF. Anal Chem. 2012; 84:10485. [PubMed: 23121341] 

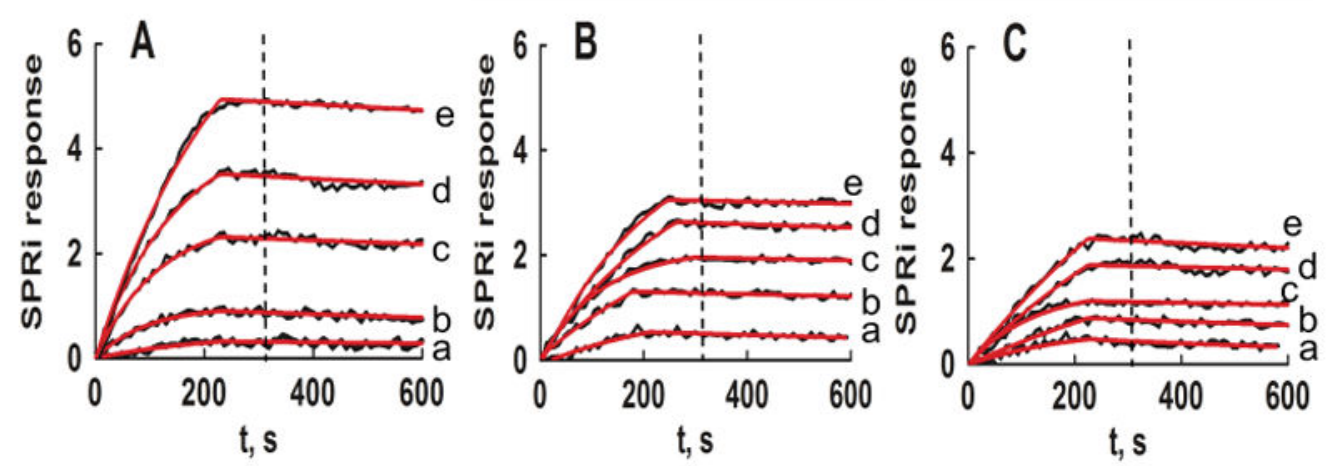

Figure 1.

Relative SPR responses for free IgE at concentrations a- $7.5 \mathrm{nM}$, b- $20 \mathrm{nM}$, c- $30 \mathrm{nM}$, d- 60 $\mathrm{nM}$, e- $120 \mathrm{nM}$ binding at $\mathrm{pH} 7.2$ to (A) Anti-Human IgE; (B) Ara-h2 peptide; (C) BXG at $50 \mu \mathrm{L} \mathrm{\text {min}^{-1 }}$ flow rate. (— Experimental data, — best fit onto eqs. 1 and 2 ) 

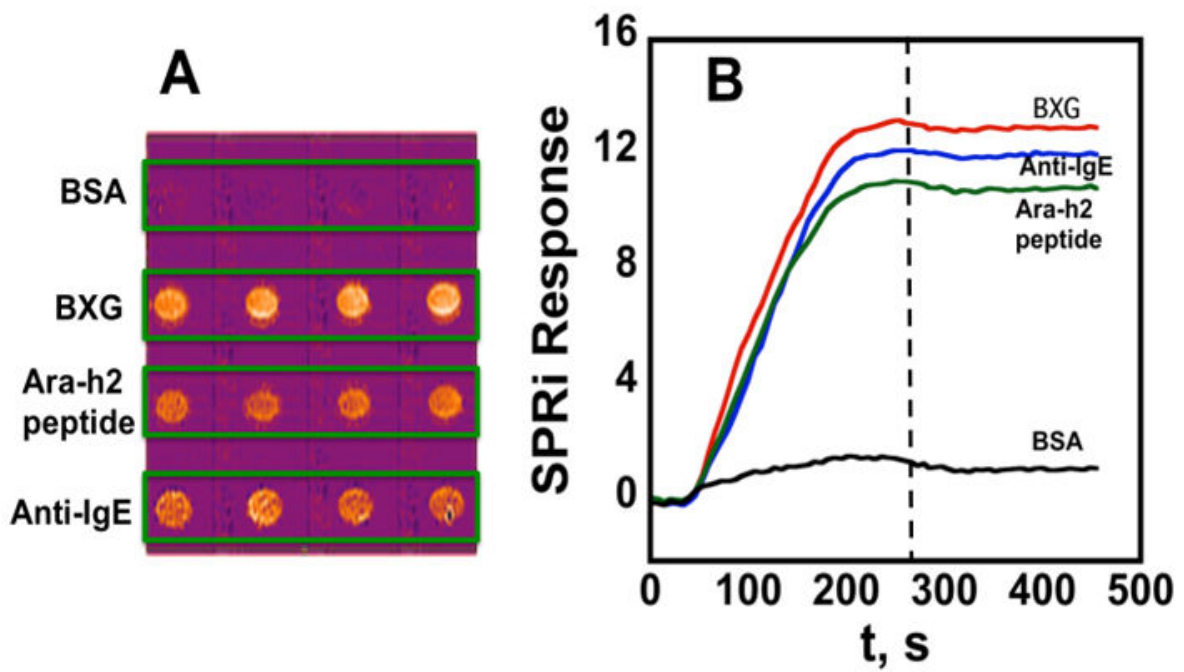

Figure 2.

SPRi of human IgE binding to BXG, Ara-h2 peptide, and anti-IgE spots: (A) Difference image for $10 \mathrm{pg} \mathrm{mL}^{-1}$ human IgE in 1000-fold diluted calf serum pre-captured onto antibody-coated magnetic particles. Spots for different detection probes are labeled within the green boxes; B) real-time SPR response curves for individual detection probes during binding of $10 \mathrm{pg} \mathrm{mL}^{-1}$ human IgE pre-captured onto antibody coated magnetic particles. 

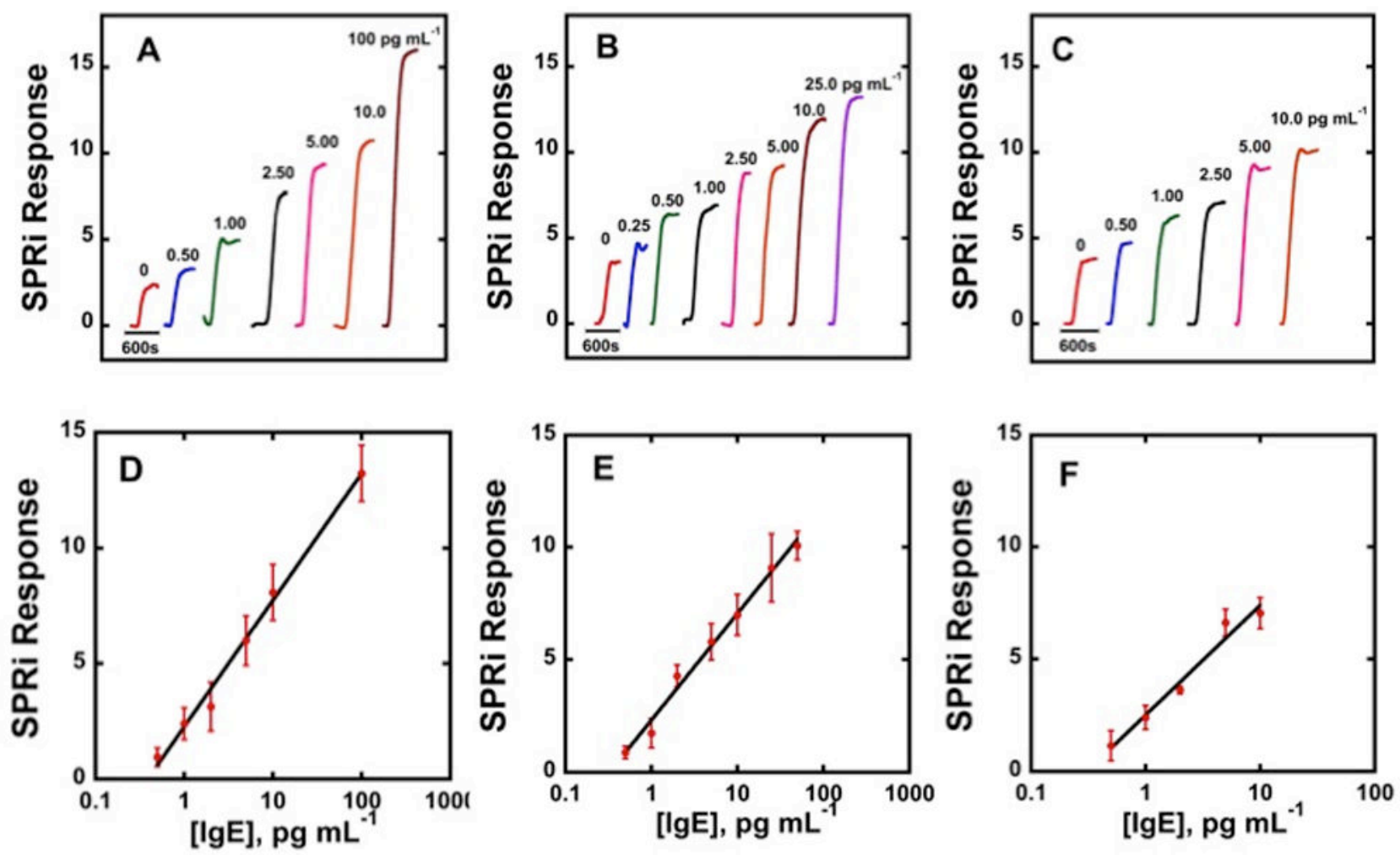

Figure 3.

Background subtracted response curves for human IgE (40 $\mu \mathrm{L}$ standard solutions) precaptured on $\mathrm{MP}-\mathrm{Ab}_{2}$ and injected in buffer at $50 \mu \mathrm{L} \mathrm{min}-1$ to surface immobilized A) Monoclonal Anti-Human IgE, B) BXG C) Ara-h2 peptide. (D-F) Calibration plots of standard human IgE in 1000-fold diluted calf serum on (D) Anti-Human IgE; (E) BXG, (F) Ara-h2 peptide spots. Error bars represent standard deviations for $n=4$ 


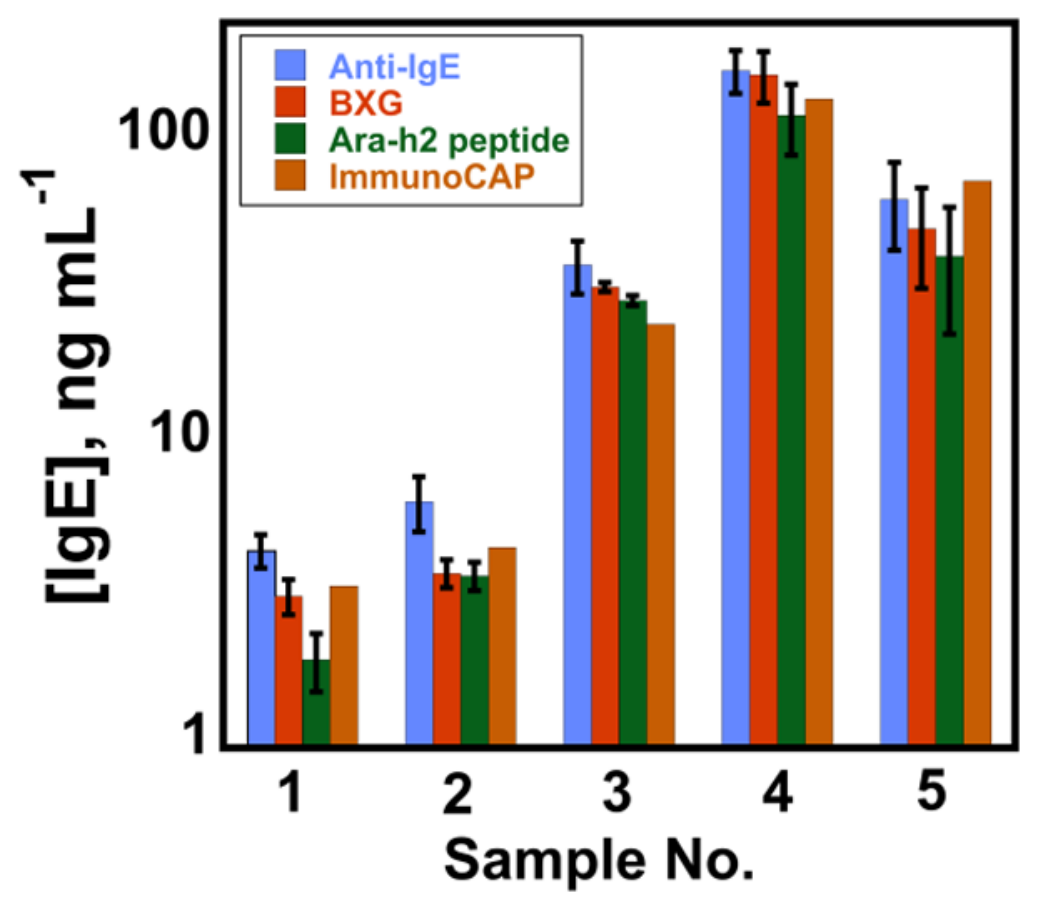

Figure 4.

Correlation of SPRi microarray results for patient serum samples using offline capture of IgEs by magnetic beads compared to standard ImmunoCAP assays. 


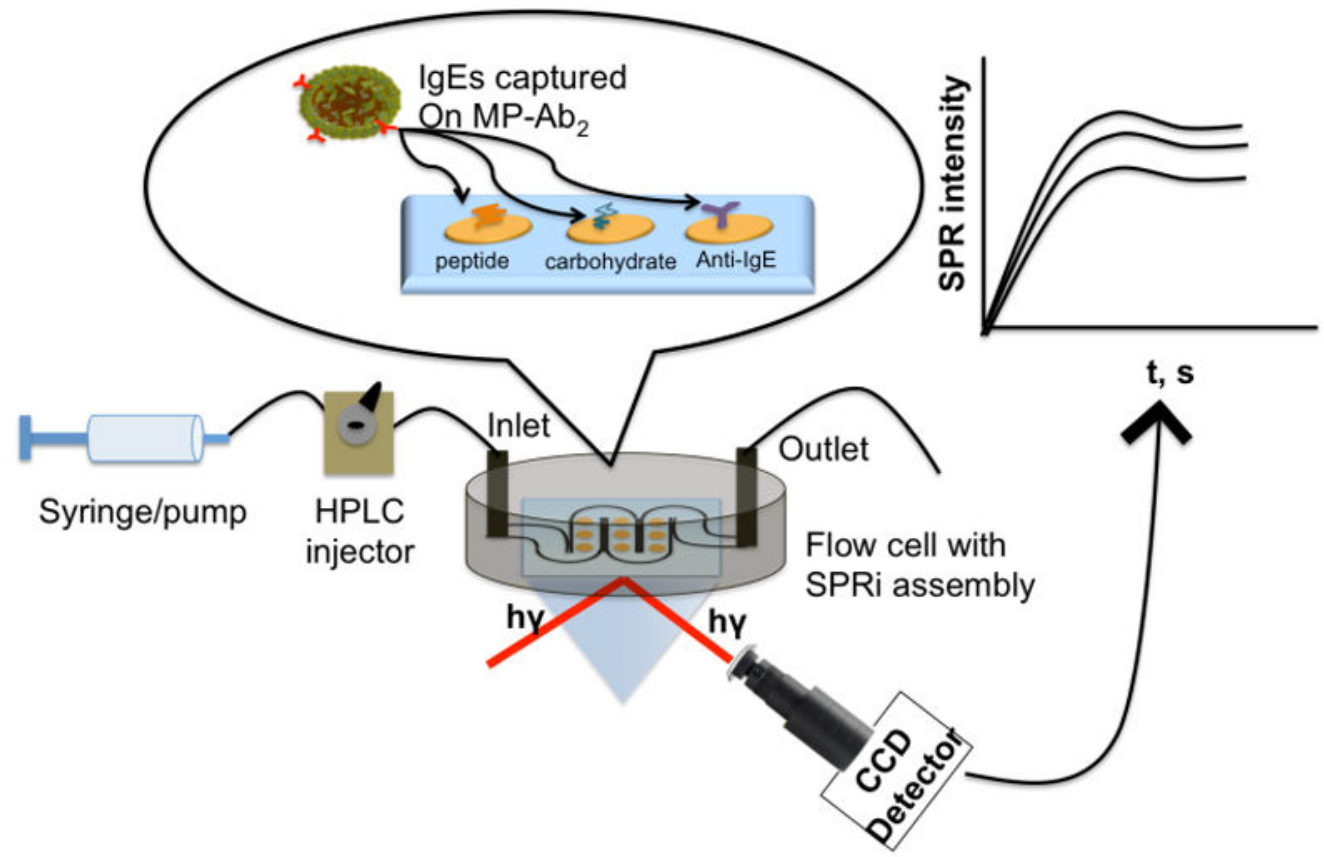

Scheme 1.

SPRi microarray configured to detect IgE binding to Ara $\mathrm{h} 2$ peptide, $\mathrm{BXG}$, and anti-IgE using antibody-loaded magnetic particles (MP- $\left.\mathrm{Ab}_{2}\right)$ for capture and signal amplification. 


\section{Table 1}

Parameters of allergen specific antibodies IgY and IgE binding to allergen Ara-h2 peptide and BXG spots.

\begin{tabular}{cllll}
\hline Analyte & Probe & Association, $\mathbf{k}_{\mathbf{a}}\left(\mathbf{M}^{-\mathbf{1}} \mathbf{s}^{-\mathbf{1}}\right)$ & Dissociation, $\mathbf{k}_{\mathbf{d}}\left(\mathbf{s}^{-\mathbf{1}}\right)$ & $\mathbf{K}_{\mathbf{D}}(\mathbf{n M})$ \\
\hline \multirow{2}{*}{ Chicken IgY } & Ara-h2 peptide & $2.9 \pm 0.6 \times 10^{5}$ & $1.2 \pm 0.2 \times 10^{-3}$ & $4.1 \pm 0.2$ \\
& BXG & $2.4 \pm 0.8 \times 10^{5}$ & $1.7 \pm 0.1 \times 10^{-3}$ & $6.8 \pm 1.0$ \\
\hline \multirow{2}{*}{ Human IgE } & Anti-IgE & $2.4 \pm 1.0 \times 10^{5}$ & $0.29 \pm 0.06 \times 10^{-3}$ & $1.3 \pm 0.5$ \\
& Ara-h2 peptide & $1.8 \pm 0.8 \times 10^{5}$ & $0.27 \pm 0.07 \times 10^{-3}$ & $1.6 \pm 0.6$ \\
& BXG & $1.1 \pm 0.8 \times 10^{5}$ & $0.29 \pm 0.03 \times 10^{-3}$ & $2.6 \pm 1.1$ \\
\hline
\end{tabular}

